\title{
Pharmaciana
}

Vol.10, No.2, July 2020, Page. $193-200$

ISSN: 2088 4559; e-ISSN: 24770256

DOI: $10.12928 /$ pharmaciana.v10i2.13514

\section{Evaluation of sperm quality in male rats treated with Sauropus androgynus (L.) merr. leaf fractions}

\author{
Ni Putu Ermi Hikmawanti, Numlil Khaira Rusdi*, Silvy Yulida \\ Faculty of Pharmacy and Sciences, Universitas Muhammadiyah Prof. DR. HAMKA \\ Jl. Delima II/IV Islamic Center, Klender, Jakarta Timur, Indonesia
}

Submitted: 05-07-2020

Reviewed: 05-07-2020

Accepted: 07-08-2020

\begin{abstract}
Sauropus androgynus (L.) Merr. or katuk is one of the medicinal plants broadly used in Indonesia as it has active compounds that can, among others, stimulate reproductive hormones. This study was aimed to determine which active fraction of $S$. androgynus leaves that have the potential to improve the sperm quality of male rats based on three parameters, namely sperm count, viability, and motility. It employed fractionation using the liquid-liquid extraction with $n$-hexane, ethyl acetate, and water solvents to obtain the fractions. Twenty-four mature Sprague-Dawley male rats were divided into four equal groups: the normal group (untreated group) received $0.5 \% \mathrm{Na}$-CMC suspense, and the three fraction groups were given the $n$-hexane, ethyl acetate, and water fraction p.o., respectively, at the dose of $11.85 \mathrm{mg} \cdot \mathrm{Kg}^{-1} \mathrm{BW}$ daily for seven days. Sperm count, viability, and motility were measured on day 8 (after treatment) from the sperm samples collected at the cauda epididymis of the sacrificed test rats. The results showed that compared with the normal group, the $n$-hexane and ethyl acetate fractions significantly increased the three parameters $(\mathrm{p}<0.05)$. Therefore, the $S$. androgynus leaf fractions have the potential as a natural material that can increase the fertility of male rats.
\end{abstract}

Keywords: fertility, fractions, katuk, Sauropus androgynus, sperm

\footnotetext{
*Corresponding author:

Numlil Khaira Rusdi

Faculty of Pharmacy and Sciences, Universitas Muhammadiyah Prof. DR. HAMKA

Jl. Delima II/IV Islamic Center, Klender, Jakarta Timur, Indonesia

Email: numlil_khaira@yahoo.com
} 


\section{INTRODUCTION}

Infertility is defined as "Clinical pregnancy failure after 12 months or more of regular unprotected sexual intercourse" (World Health Organization, 2020). No less than 50 percent of cases are responsible for male infertility. Essentially, identified contributors to sperm dysfunction and male infertility factor are primarily environmental, physiological, and genetic (World Health Organization, 2010). Analysis of semen is still the first step in male infertility diagnosis, which is commonly perceived as a change in sperm concentration, motility, morphology, or its combination.

Among the proposed mechanisms which lead to impaired spermatogenesis are increased ROS and oxidative levels (oxidative stress). Conditions of male infertility in humans primarily oligospermia and asthenozoospermia. This can be caused by a complete dietary loss of antioxidants and a vitamin A deficiency or other elements such as flavonoids, phenolic and folate (Ouladsahebmadarek et al., 2016). It has long been thought that the use of herbs by men with infertility could improve the sperm parameters or regulate male reproductive hormones associated with the spermatogenesis process. Indonesia is a country rich in plants that can be made as traditional medicine, one of which is Sauropus androgynus (L.) Merr. or they are known as katuk. The ethanol extract of S. androgynus leaves contains steroids, tannins, alkaloids, flavonoids, and terpenoids (Rusdi et al., 2018). S. androgynus leaf extract can increase viability, motility, and concentration of spermatozoa in male mice exposed to cigarette smoke when administered at the dose of $6 \mathrm{mg} / 20 \mathrm{~g} \mathrm{BW}$ (Khoironi, 2015). Rusdi et al., (2018) reported that the $n$-hexane fraction at a dose of $11.85 \mathrm{mg} . \mathrm{Kg}^{-1} \mathrm{BW}$ can increase the sexual desire of male rats toward female rats, as observed from the number of mounts and precopulatory investigations, and the weight of testicular and vesicular of male rats.

Thus, an active fraction of $70 \%$ ethanol extract of $S$. androgynus leaves was analysed for its effectiveness as medicinal ingredients in increasing sperm count, viability, and motility in male rats.

\section{MATERIALS AND METHOD}

\section{Materials}

\section{Plant sample and authentication}

The fresh $S$. androgynus leaves were obtained from the Indonesian Medicinal and Aromatic Crops Research Institute (BALITTRO), Bogor. It was authenticated at the Botanical Research and Development Centre "Herbarium Bogoriense" LIPI, Bogor.

\section{Experimental animals}

Twenty-four male Sprague Dawley sexually mature rats aged 2-3 months and weighing around 150-250 g were obtained from Research Animal Breeder, Bekasi. These rats were kept in a wellventilated house with 12-hour light and 12-hour dark period. Rats were given pelleted feed and ad libitum access to water.

\section{Methods}

\section{Preparation of fractions}

The dried powder of $S$. androgynus leaves $(1.43 \mathrm{Kg})$ was macerated using ethanolic solvent for 24 hours. The filtrate was separated from the pulp by filtration. While the pulp was extracted again with $70 \%$ ethanol using the same procedure up to three times, the filtrate was evaporated using a vacuum rotary evaporator N-1200 BS series (EYELA, Shanghai, China) until thick extract was obtained. A known quantity (306.52 g) of the thick ethanol extract was fractionated with water and $n$ hexane solvents in a separating funnel and left to form two phases. Afterwards, the two phases were separated. This procedure was also applied to fractionation with ethyl acetate. Finally, the $n$-hexane, ethyl acetate, and water fractions were evaporated to produce fractions in their thick forms (Suprayogi et al., 2015). 


\section{Phytochemical screening of active fractions using TLC method}

Phytochemical screening was carried out by the TLC method to examine the presence of steroids and flavonoids in the active fraction that, in this procedure, was dissolved in ethanol. The TLC method used silica gel GF254 (Merck) as the stationary phase, while two different mobile phases were used to each detect the presence of steroid and flavonoid compounds. The mobile phase used to identify the presence of steroid compounds was chloroform:methanol (10:1), with vanillin-sulfuric acid as the detection reagent. Meanwhile, the mobile phase used to detect flavonoid compounds was $n$ hexane:ethyl acetate (1:1), with ammonia vapour as the detection reagent (Hanani, 2015).

\section{Test animal preparation}

The animals under test were divided into four groups, each consisting of six rats. Before receiving the treatment, they were acclimatized for seven days, fed with pelleted rat feed, and allowed access to water ad libitum. Protocol no. 17-05-0438 was approved by the Health Research Ethics Committee of the Faculty of Medicine, Universitas Indonesia no. 631/UN2.F1/ETIK/2017.

\section{Test animal treatment}

All four groups received different treatments for seven days: Group I (normal control group) was given Na-CMC $0.5 \%$ each day, while Groups II, III, and IV were given the fractions ( $n$-hexane, ethyl acetate, and water), respectively at the dose of $11.85 \mathrm{mg} . \mathrm{Kg}^{-1} \mathrm{BW}$ per day. On day 8 , they were injected with ketamine at the dose of $33.35 \mathrm{mg} . \mathrm{Kg}^{-1} \mathrm{BW}$ i.m. furthermore sacrificed by cervical dislocation. The caudal epidididymis was separated carefully from the testis. It was lacerated with scissors and was collected for analysis of sperm counts, motility and viability

\section{Sperm count analysis}

After removing the caudal epididymis from the left and right samples, the sperm count was evaluated. Then, it was cut into pieces, mixed with Ringer's solution, and left for 2 minutes. Ten $\mu \mathrm{L}$ of the semen suspension was collected and inserted into the haemocytometer. It was immediately examined at $\mathrm{x} 40$ magnification under the microscope (Olympus Co., Tokyo, Japan) (Quadri and Yakubu, 2017).

\section{Sperm motility test}

Ten $\mu \mathrm{L}$ of the semen suspension in Ringer's solution was collected and inserted into the hemocytometer. Any moving and immovable spermatozoa under the microscope at $\times 40$ magnification was immediately examined. Progressive and non-progressive movement of sperm cells under the microscope describes motile sperm cells. It was calculated according to the number of motile sperm cells divided by the total number of sperm cells counted (Quadri and Yakubu, 2017).

\section{Sperm viability test}

Ten $\mu \mathrm{L}$ of the semen suspension in Ringer's solution was collected, dropped into the object's glass, then added with one drop of $2 \%$ eosin. After homogenized, it was covered with a cover glass. The stained cells were observed under a microscope at 40x magnification. The live sperm cells were unstained (transparent), while the dead ones absorbed the stain (red colour). Sperm viability is expressed in percentage (Quadri and Yakubu, 2017).

\section{Data Analysis}

One-way ANOVA followed by a Tukey 's test was used to analyzed data to find significantly different means $(\mathrm{p}<0.05)$. 


\section{RESULTS AND DISCUSSION}

The extraction yield of $S$. androgynus leaves dried powder by cold maceration with $70 \%$ ethanol was $21.99 \%$ (w/w). In extracts obtained with $70 \%$ ethanol, more bioactive flavonoids were detected. It is because of its higher polarity compared to absolute ethanol as an extraction solvent. Ethanol is the solvent used for extracting active compounds such as tannins, polyphenol, flavonoids, terpenoids, steroids, and alkaloids (Tiwari et al., 2011).

The percentage yields of the $n$-hexane, ethyl acetate, and water fractions from ethanolic extract using the liquid-liquid extraction method were $1.74 \%, 5.29 \%$, and $52.94 \%(\mathrm{w} / \mathrm{w})$, respectively. The $n$ hexane can dissolve non-polar compounds such as fixed oils, volatile oils, steroids, and several flavonoids aglycon. Semi-polar solvents such as ethyl acetate can dissolve alkaloids and the other aglycon like flavonoids (Houghton and Raman, 1998). Water as an extraction solvent can extract polar metabolite materials such as quaternary alkaloids, phenolic, carotenoids, tannins, glycoside flavonoids, sugar, amino acids, and the other glycosides (Hanani, 2015).

Male rats were receiving $n$-hexane and ethyl acetate fractions (Groups II and III) showed a significant increase in the sperm count, motility, and viability $(\mathrm{P}<0.05)$ compared to the normal control group (Group I) (Figures 1-3). The presence of steroids in the $n$-hexane fraction and flavonoids in the ethyl acetate fraction was identified using the TLC method (Figure 4).

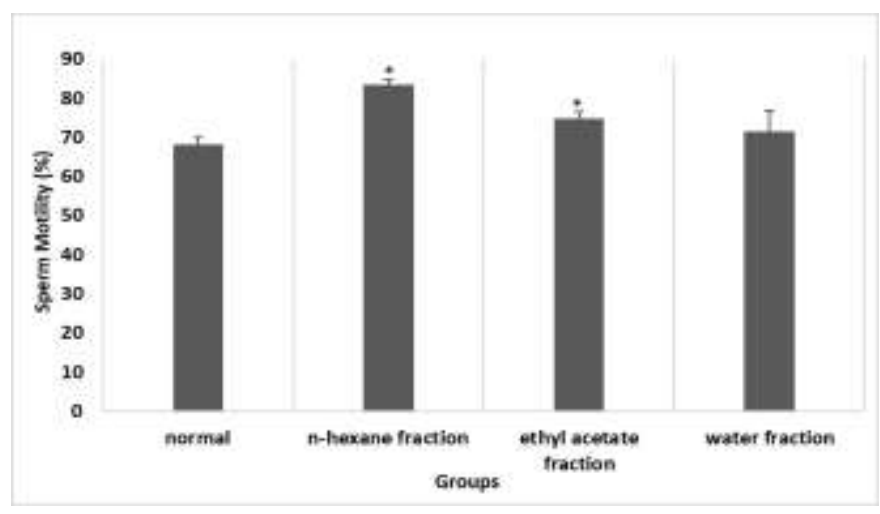

Figure 1. Effects of $S$. androgynus leaf fractions on sperm motility in male rats (Note: $*=$ a significant difference with the normal group $(\alpha=0.05)$ )

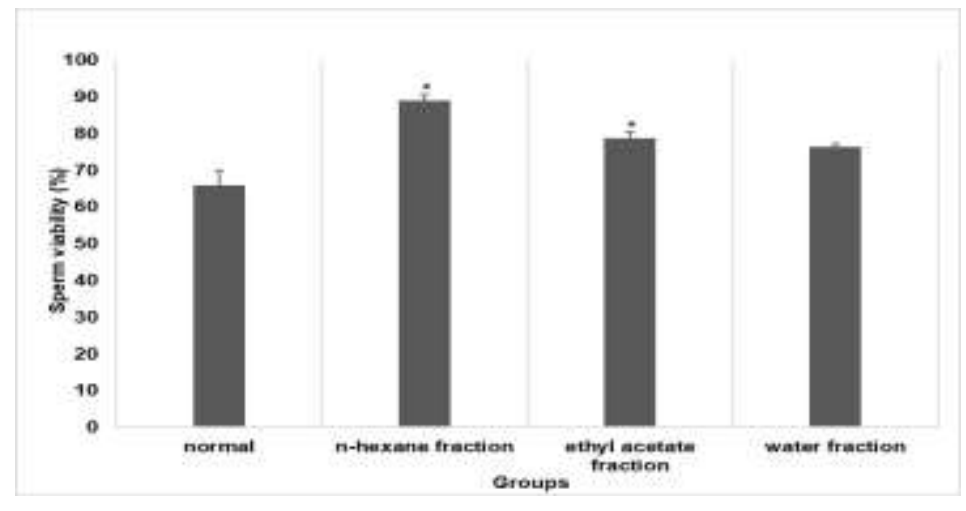

Figure 2. Effects of $S$. androgynus leaf fractions on sperm viability in male rats (Note: * a significant difference with the normal group $(\alpha=0.05)$ ) 


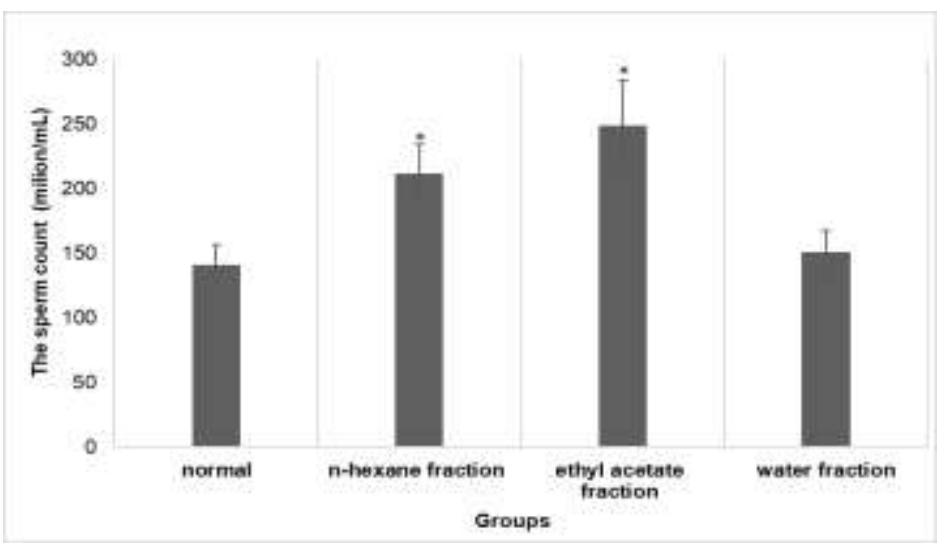

Figure 3. Effects of $S$. androgynus leaf fractions on sperm count in male rats (Note: $*$ a significant difference with the normal group $(\alpha=0.05)$ )
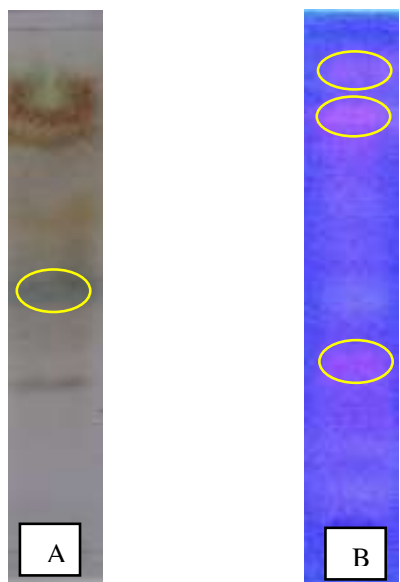

Figure 4. The presence of steroid compounds in the $n$-hexane fraction (A) and flavonoid compounds in the ethyl acetate fraction (B) of $S$. androgynus leaves, identified using the TLC method

Fragmentation of DNA in spermatozoa induced by Reactive Oxygen Species (ROS) and oxidative stress is now identified as a significant factor in male infertility aetiology. DNA damage occurs in men with both abnormal and normal semen parameters. ROS are produced and required in spermatozoa for several specific and essential functions. when ROS concentrations increase and/or antioxidant defenses get overwhelmed, oxidative stress occurred. It causes damage to components of the cells, especially lipids, proteins, and DNA. The lipid peroxidation and DNA damage are two major effects of oxidative stress affecting fertility (Wright et al., 2014).

In general, antioxidants can remove, scavenge and hold back the production of ROS or neutralize their actions (Adewoyin et al., 2017). Primary antioxidants are mainly phenolics in structure and include the following: antioxidant minerals, antioxidant vitamins, and phytochemicals, such as flavonoids, catechins, carotenoids, $\beta$-carotene, and lycopene (Moharram and Youssef, 2014). All of which have been described as having the effect of reducing risk of disease, as free radicals can be 
scavenged. Effects on flavonoids antioxidants, mainly $p$-cymene and carvacrol, in the essential oil of Satureja khuzestanica due to their ability to decrease ROS (Safarnavadeh and Rastegarpanah, 2011).

Several phytomedicines, including phenolic compounds (phenolics, sterols, lignans, and flavonoids), volatile oils, and saponins, are found in dietary supplements. They have been shown to increase sperm parameters (sperm motility, count and viability) and have positive effects on spermatogenesis (Khojasteh et al., 2016; Adewoyin et al., 2017). Also, previous study have reported that the fractions of $S$. androgynus leaves can increase the weight of testicular and seminal vesicle (Rusdi et al., 2018). In this study, $n$-hexane and ethyl acetate fractions induced improvements in semen quality and quantity. This activity probably related to the presence of flavonoids and steroids as active compounds in both fractions (see Figure 4). Flavonoids can increase dehydroepiandrosterone (DHEA) levels, which plays a role in increasing testosterone levels. Saponins, in the form of steroid glycosides, contribute to the DHEA biosynthesis, hence, increasing testosterone levels in the body (Andini, 2014). Multiplied sperm number in treated rats groups is due to increased production of male reproduction hormone (Al-Sa'aidi et al., 2009). The process of spermatogenesis is associated with testosterone and follicle-stimulating hormone (FSH) levels (McLachlan, 2004). Further studies should focus on mechanism by which fractions improve spermatogenesis through the cellular and intracellular signalling pathways.

\section{CONCLUSION}

The $n$-hexane and ethyl acetate fractions of $S$. androgynus leaves have the potential to be developed into natural male fertility-enhancing agents.

\section{ACKNOWLEDGEMENT}

We would like to thank the Research and Development Institute (Lembaga Penelitian dan Pengembangan) of Universitas Muhammadiyah Prof. DR. HAMKA, Jakarta, for financially assisting this research under the Funding Grant Scheme of Science and Technology Development Research Batch II 2018.

\section{REFERENCES}

Adewoyin, M., Ibrahim, M., Roszaman, R., Isa, M., Alewi, N., Rafa, A., \& Anuar, M. (2017). Male infertility: the effect of natural antioxidants and phytocompounds on seminal oxidative stress. Diseases, 5(9), 1-26. https://doi.org/10.3390/diseases5010009.

Al-Sa 'aidi, J. A. A., Al-Khuzai, A. L. D., \& Al-Zobaydi, N. F. H. (2009). Effect of alcoholic extract of Nigella sativa on fertility in male rats. Iraqi Journal of Veterinary Sciences Supplement II, 23, $123-128$.

Andini, D. (2014). Potential Of katuk leaf (Sauropus androgynus L. Merr) as aphrodisiac. Journal Majority, 3(7), 16-21.

Hanani, E. (2015). Analisis Fitokimia. Jakarta: Buku Kedokteran EGC.

Houghton, P. J., \& Raman, A. (1998). Laboratory handbook for the fractionation of natural extracts. Laboratory Handbook for the Fractionation of Natural Extracts. https://doi.org/10.1007/978-14615-5809-5.

Khoironi, I. (2015). Pengaruh ekstrak daun katuk (Sauropus androgynus (L.) Merr) terhadap konsentrasi spermatozoa pada mencit Balb/c jantan yang diberi paparan asap rokok. Universitas Islam Sultan Agung.

Khojasteh, S. M. B., Khameneh, R. J., Houresfsnd, M., \& Yaldagard, E. (2016). A review on medicinal plants used for improvement of spermatogenesis. Biology and Medicine, 8(4), 1-7.

McLachlan, R. I. (2004). Identification of specific sites of hormonal regulation in spermatogenesis in rats, monkeys, and man. Recent Progress in Hormone Research, 57(1), 149-179. 
Moharram, H. A., \& Youssef, M. M. (2014). Methods for determining the antioxidant activity: a review. Alexandria Journal of Food Science and Technology, 11(1), 31-42. https://doi.org/10.12816/0025348.

Ouladsahebmadarek, E., Giasi, G. S., Khaki, A., Ahmadi, Y., Farzadi, L., Ghasemzadeh, A., \& Hajizade, K. (2016). The effect of compound herbal remedy used in male infertility on spermatogenesis and pregnancy rate. International Journal of Women's Health and Reproduction Sciences, 4(4), 195-198. https://doi.org/10.15296/ijwhr.2016.41.

Quadri, A. L., \& Yakubu, M. T. (2017). Fertility enhancing activity and toxicity profile of aqueous extract of Chasmanthera dependens roots in male rats. Andrologia, 49(10), 1-15.

Rusdi, N. K., Hikmawanti, N. P. E., Maifitrianti;, Ulfah, Y. S. ., \& Annisa, A. T. (2018). Aktivitas afrodisiaka fraksi dari ekstrak etanol 70\% daun katuk (Sauropus androgynus (L.) Merr) pada tikus putih jantan. Pharmaceutical Sciences and Research (PSR), 5(3), 123-132.

Safarnavadeh, T., \& Rastegarpanah, M. (2011). Antioxidants and infertility treatment, the role of Satureja Khuzestanica: A mini-systematic review. Iranian Journal of Reproductive Medicine, 9(2), 61-70.

Suprayogi, A., Kusumorini, N., \& Arita, S. E. . (2015). Fraksi heksan daun katuk sebagai obat untuk memperbaiki produksi susu, penampilan induk, dan anak tikus. Jurnal Veteriner, 16(1), 88-95.

Tiwari, P., Kumar, B., Kaur, M., Kaur, G., \& Kaur, H. (2011). Phytochemical screening and Extraction: A Review. Internationale Pharmaceutica Sciencia, 1(1), 98-106. https://doi.org/10.1002/hep.29375.

World Health Organization. (2010). WHO laboratory manual for the examination of human semen, 5th $E d$. World Health Organization.

World Health Organization. (2020). Sexual and reroductive health: multiple definitions of rertility. Retrieved from. Retrieved from https://www.who.int/reproductivehealth/topics/infertility/multiple-definitions/en/.

Wright, C., Milne, S., \& Leeson, H. (2014). Sperm DNA damage caused by oxidative stress: modifiable clinical, lifestyle and nutritional factors in male infertility. Reproductive BioMedicine Online, 28, 684-703. 
